\title{
Atlas topographique des villes de la Gaule méridionale
}

Projet collectif de recherche (2013)

Marc Heijmans

\section{(2) OpenEdition \\ Journals}

Édition électronique

URL : https://journals.openedition.org/adlfi/15008

ISSN : 2114-0502

Éditeur

Ministère de la Culture

Référence électronique

Marc Heijmans, « Atlas topographique des villes de la Gaule méridionale » [notice archéologique],

ADLFI. Archéologie de la France - Informations [En ligne], Auvergne-Rhône-Alpes, mis en ligne le 16 juillet 2015, consulté le 28 mai 2021. URL : http://journals.openedition.org/adlfi/15008

Ce document a été généré automatiquement le 28 mai 2021.

(C) ministère de la Culture et de la Communication, CNRS 


\title{
Atlas topographique des villes de la Gaule méridionale
}

\author{
Projet collectif de recherche (2013)
}

\section{Marc Heijmans}

\section{NOTE DE L'ÉDITEUR}

Organisme porteur de l'opération : CNRS

1 L'année 2013 marque la première année du huitième programme triennal de recherche (2013-2015) du groupe de travail sur la "Topographie urbaine de Gaule méridionale », qui regroupe depuis le début des années 1990 des chercheurs de trois régions (LanguedocRoussillon, Provence-Alpes-Côte d'Azur, Rhône-Alpes) issus des universités, du CNRS, de l'Inrap, des collectivités territoriales et des associations. Du fait de son interrégionnalité, le PCR est financé à tour de rôle par l'une des trois régions concernées ; pour le triennal 2013-2015, c'est la région Rhône-Alpes.

2 Rappelons que l'objectif du PCR est la publication de fascicules d'un Atlas topographique des villes de Gaule méridionale, c'est-à-dire d'abord des chefs-lieux de cités antiques des provinces augustéennes de Narbonnaise et des Alpes Maritimes, qui comprendrait un jeu de feuilles représentant sur un fond cadastral simplifié à échelle 1/1000 tous les vestiges cartographiables, assorti d'un commentaire pour chaque feuille et suivi d'une synthèse générale sur l'histoire et la topographie de la ville, pour une période allant des origines à l'entrée des deux anciennes provinces romaines dans le regnum Francorum. Trois volumes ont été publiés jusqu'à présent, le premier, consacré à Aix (1998), le second à Fréjus (2000), et au tout début de 2010 est sorti le troisième volume, consacré à la ville de Saint-Paul-Trois-Châteaux. Comme les deux précédents, il est paru dans la collection des suppléments de la Revue archéologique de Narbonnaise.

Les réunions de l'année 2013 ont concerné essentiellement les Atlas d'Alba-la-Romaine/ Viviers, d'Arles et de Nîmes. Une discussion a été engagée avec les SRA, le CNRA et 
l'Inspection concernant l'avenir de ce projet. Une séance du CNRA en novembre 2013 a été consacrée à cette question.

\section{INDEX}

\section{Année de l'opération : 2013}

nature https://ark.frantiq.fr/ark:/26678/crtqI2kNablQH

lieux https://ark.frantiq.fr/ark:/26678/pcrtSEeAipsBlD, https://ark.frantiq.fr/ark:/26678/ pcrtvVEJGc5bsY, https://ark.frantiq.fr/ark:/26678/pcrtVqtsfM4Yn0, https://ark.frantiq.fr/ark:/ 26678/pcrtbE3vzlaX00, https://ark.frantiq.fr/ark:/26678/pcrtVacUtHvsRG, https:// ark.frantiq.fr/ark:/26678/pcrtf7kqWDJiK5, https://ark.frantiq.fr/ark:/26678/crtB8WDyqd6u9, https://ark.frantiq.fr/ark:/26678/pcrtKgdLgiLWKX, https://ark.frantiq.fr/ark:/26678/ pcrtP0VJP5Ni0Z, https://ark.frantiq.fr/ark:/26678/pcrtJlOy6OeKRi, https://ark.frantiq.fr/ark:/ 26678/pcrtFwuExfWRlE, https://ark.frantiq.fr/ark:/26678/pcrtZVqHwhrSy8, https:// ark.frantiq.fr/ark:/26678/pcrtliYsR97seb, https://ark.frantiq.fr/ark:/26678/crtF7tPQuwu5w, https://ark.frantiq.fr/ark:/26678/pcrt8e6lvcimFS, https://ark.frantiq.fr/ark:/26678/ pcrtD5AWjBs3w4

chronologie https://ark.frantiq.fr/ark:/26678/pcrtxT02uJOogm, https://ark.frantiq.fr/ark:/ 26678/pcrtof7EHNsS2e, https://ark.frantiq.fr/ark:/26678/pcrtZTmusVUU24 sujets https://ark.frantiq.fr/ark:/26678/pcrtWthF204SuS, https://ark.frantiq.fr/ark:/26678/ pcrtKJVpuP3AET, https://ark.frantiq.fr/ark:/26678/pcrtDlzbGxWvTo, https://ark.frantiq.fr/ ark:/26678/pcrtbptj4SOA1W, https://ark.frantiq.fr/ark:/26678/pcrthXosl9QxQ2, https:// ark.frantiq.fr/ark:/26678/pcrtN5zGcqx0YR, https://ark.frantiq.fr/ark:/26678/pcrthT7f96LxBR

\section{AUTEURS}

\section{MARC HEIJMANS}

CNRS 